Rupkatha Journal on Interdisciplinary Studies in Humanities (ISSN 0975-2935), Vol. 10, No. 1, 2018 Special Issue on "Interrogating Cultural Translation: Literature and Fine Arts in Translation and Adaptation" In collaboration with the Department of English, Amrita Vishwa Vidyapeetham Guest-edited by Dr. Hari M G, Amrita Vishwa Vidyapeetham, Coimbatore, India

DOI: https://dx.doi.org/10.21659/rupkatha.v10n1.07

Full Text: http://rupkatha.com/V10/n1/v10n107.pdf

\title{
Deconstructing Culture/Violence in Distant Star and By Night in Chile
}

\author{
Mandeep Boro \\ Amrita Vishwa Vidyapeetham, Ettimadai \\ orcid.org/oooo-ooo1-9671-9527. Email: b_mandeep@cb.amrita.edu
}

Received September 27, 2017; Revised December 11, 2017; Accepted December 30, 2017; Published February 04, 2018.

\begin{abstract}
In Roberto Bolaño's Distant Star (1996), Carlos Wieder embarks on a journey to change the landscape of Chilean literature. Yet it is through physical torture, murder, violence and photographic exhibitions of mutilated dead bodies that he seeks to bring in the literary transformation. He is a poet but also a professional serial killer. Funded by dictatorial regime his poetic acts include writing macabre verses with smokes of airplane in the sky. In another novella By Night in Chile (200o) by the same author, intellectuals organize tertulias to discuss philosophy, politics, poetry, art while the military junta torture people in the basement of the same building. Thus, culture and violence overlap in these texts and they lead to the problematic core of our understanding/conceptualization of literary culture as the stories told in these narratives put the literary institutions in crisis mode and blur the line between what is called culture and violence. This paper explores these issues and argues that the Bolañian novels by narrating such stories surpass the limits of the law, transgress, devalue the traditional notion of literature and completely strip it off its aura by enmeshing arts and violence together. They thus deconstruct the popular myths related to literary culture.
\end{abstract}

Keywords: Roberto Bolaño, literature, culture, violence.

\section{Introduction}

Roberto Bolaño (1953 - 2003) was a Chilean writer. He won the 1999 Rómulo Gallego Prize for his novel Los detectives salvajes (1998) which was later translated and published as The Savage Detectives (2007) in English. Although he was Chilean by birth, he always considered himself a Latin American writer. Culture and violence are major and recurrent themes in his writings. By the term "culture" I mean literary culture, Bolaño's discourse on literature in general, and poetry in particular, or the literary discourse. Whether it's Amulet, By Night in Chile, Distant Star, Nazi Literature in the Americas, The Savage Detectives or his last apocalyptic, monumental and posthumous narrative 2666 , all these texts deal with these themes in one way or the other. The search for a poet or a novelist occupies central place in many of his novels. The readers also come across these themes in his short stories, poetry, articles, essays, speeches and even in his interviews. Bolaño's characters are often poets, critics and novelists. If some of them are aspiring poets, others appear as already established literary critics and writers. Yet many poets and

(C) Authors. Published by AesthetixMS under a Creative Commons Attribution Non-Commercial 4.0 International License (http://creativecommons.org/licenses/by-nc/4.0/). 
novelists also figure as right wing fascist writers who collude with the repressive regimes and carry out their atrocious designs. It's through these characters that Bolaño speaks and represents the theme of culture and violence in his writings. Another distinguishing trait of Bolaño's narratives is that quite often both real writers and imaginary writers appear as characters and at times it is extremely difficult to draw a dividing line between these characters since most of the stories are also largely based on true events and persons.

In this paper I look at the fine zone where culture and violence coincide or overlap in two of Bolaño's novels Distant Star (1996) and By Night in Chile (2000). The overlap of culture and violence in these narratives problematizes our understanding/conceptualization of literature/poetry as such as the stories told in these narratives put the literary institutions in crisis mode, blur the line between what is called culture and violence. By dwelling on how culture and violence are articulated, perpetuated, represented and staged through these texts I argue that the Bolañian novels by narrating such stories surpass the limits of the law, transgress, devalue the traditional notion of literature and completely strip it off its aura by enmeshing arts and violence together. They thus deconstruct the popular myths related to literary culture.

\section{Writing poetry in the sky}

The novella Distant Star, like other texts by Bolaño, initiates in a poetry workshop and ends in torture, violence and murder. The novel can, thus, be read as a journey or voyage from civilization to barbarism/culture to violence. Walter Benjamin's famous quote that "There is no document of culture which is not at the same time a document of barbarism" (1999, p. 248) precisely describes the ideology behind this novel. The action takes place in Juan Stein's poetry workshop at the University of Concepción's Faculty of Literature a little while before the fall of Salvador Allende's socialist government. Young students passionate about Chilean poetry, politics, art, revolution, attend the workshop and they talk about the armed struggle that would usher a new life and a new era. It is there the unnamed narrator (presumably Bolaño) and his friend Bibiano O'Rayan meet the Garmendia sisters and they fall in love with them. However, they also meet there Alberto Ruiz-Tagle and little do they realize that he would later be known as Carlos Wieder, murderer of the Garmendia sisters, other poets and political dissidents. The presence of Alberto Ruiz-Tagle/Carlos Wieder casts a somber premonition of evil throughout the novel as the readers and the participants of Stein's poetry workshop neither recognize the catastrophe or terror in him nor realize up to what extent he is capable and willing to go to bring in transformation in Chilean poetry.

After the coup Ruiz-Tagle disappears, however, only to reappear as Carlos Wieder, lieutenant of the Chilean Air Force, and he is responsible for the disappearance, torture and death of the Garmendia sisters and several others. He carries out a series of avant-garde poetic acts that include writing macabre verses with smokes of fighter plane in the skies of Chile and Antarctica. His verses consist of lines from the Book of Genesis in Latin, and the names of the tortured and murdered women. The spectators hardly fathom the motif behind his poetry. Nonetheless, they rejoice and appreciate his aerial poetry. Indeed, Carlos Wieder receives recognition among the critics and enjoys good review in the national media. His last skywriting act involves a series of verses about death. He writes:

Death is friendship.

Death is Chile.

Death is responsibility. 
Death is growth.

Death is communion.

Death is cleansing. (Bolaño, 2009, pp. 80-81)

The term "death" merely appears as a metaphor in his skywriting poetry through which he justifies his actions. After this poetic act Wieder organizes an exclusive private photographic exhibition at his flat. The exhibition deals with photographs of tortured and mutilated bodies which were taken moments just before their death. The guests of the exhibition remark that the dead bodies mostly belonged to women and, “ ... looked like mannequins, broken, dismembered mannequins in some pictures" (Bolaño, 2009, p. 88). Up to thirty per cent of the subjects had been alive when the photographs were taken. The reader is thus left in a moral dilemma. For, on one hand, Wieder's skywriting truly "revolutionizes" Chilean poetry. In point of fact, it "transforms" Chilean poetry no matter the sinister motif behind it. On the other hand, it also initiates moral and ethical debates. Can photographic exhibition of mutilated dead bodies of the enemies taken minutes before death really be called a work of art? In his essay "The Death of the Author" Roland Barthes argues that while interpreting/analyzing a text one must not bring in the biographical context of an author. However, if one is to decipher Wieder's skywriting and photographic exhibition can his intentions be really left behind, can they be ignored?

However, Wieder's stunt does not go down well within the higher echelons of military regime. Yet instead of pleading guilty, the authorities merely expel him from the Air Force. He is forced to disappear quietly from the official map of Chilean literature but only to reemerge as photographer of pornographic films and author of several right-wing articles for European neoNazi journals.

So then the novel reflects the barbaric, horrific or savage dimension of literature/culture which, many a time, artists under different circumstances exploit it and use it as a cloak only to hide and carry out their sinister designs. The above mentioned text demonstrates that Alberto Ruiz-Tagle/Carlos Wieder is not just a poet but also a murderer, torturer, colluder with right-wing fascist regime and a professional pornographic filmmaker at the same time who kills female porn stars once the filming is completed, who is an artist who kills other artists. "Distant Star" the title of the novel refers to the star of the national flag of Chile drawn in smokes of airplane in the sky by him

As is usual in many of Bolaño's narratives, there are intercalated stories in Distant Star. The intercalated stories of the poetry workshop directors, Juan Stein and Soto Diego, suggest that violence is widespread and there is no escape from it even if the narrator, his best friend Bibiano O'Rayan and all those who witnessed the coup wanted to get away from it. Juan Stein, a left-wing sympathizer, disappears from and reappears in Chile to participate in the armed resistance in Nicaragua. His death, however, remains shrouded in mystery since nobody is able to vouch for the accuracy of the story whether he really went there, came back to Chile, lived a normal life or he died a natural death. On the contrary, Stein's best friend and rival Diego Soto opts for a comfortable life in Europe. He imposes exile on himself, goes to France, marries a Frenchwoman, lives happily there devoted to his family and literary career until one day he is killed by the neoNazis at a metro stations in Spain on his way back from a literary conference. Thus the stories of Stein and Soto suggest that literature can neither prevent violence nor tragic incidents as both of them meet the same fate. That is death at the hand of others. It is a known fact that all Latin American countries have suffered tragic events at one time or the other. However, during turbulent times literature could hardly inhibit disintegration of the community who believed in utopian dream, it could not help, rescue thousands of Chileans or Latin Americans from 
disappearance. It is in this context that literature is rendered "helpless," "hopeless" or even "worthless" in Bolaño's narratives and the idea that literature is not innocent, that it has other dimensions as well springs up. The case of Wieder demonstrates that literary culture is intricately linked with torture, murder and violence even though his skywriting can be portrayed as an avant-garde poetic acts. Thus, Bolaño does not see literature/poetry as instruments of progress, civilization, emancipation or humanization; quite the contrary.

The narrator, now settled in Barcelona, keeps track of Wieder through correspondence with his friend Bibiano O'Rayan who still lives in Santiago. When dictatorship ends and democracy is restored, Abel Romero, the Chilean detective, travels to Spain, meets the narrator and requests his help in order to track Wieder down. He tells the narrator that in order to locate a poet he needs the help of another poet and only he can help him. At that instant the narrator is baffled and he immediately tries to distance and distinguish himself from Wieder. He says, "In my opinion Carlos Wieder was a criminal, not a poet" (Bolaño, 2009, p. 117). At this the detective replies:

All right, all right, let's not be intolerant. Maybe in Wieder's opinion, or anyone else's for that matter, you're not a poet, or you're a bad one, and he's the real thing. It all depends on the glass we see through, as Lope de Vega said, don't you think?" (Bolaño, 2009, p.117, original emphasis)

Romero's reply thus erases the distinction that the narrator tries to create between himself and Wieder and in the end he ends up helping the detective who murders Wieder. For the readers and the narrator as well helping in the capture and murder of Wieder may seem like an act of justice or even poetic justice. However, it puts the narrator and the readers both in a moral zone similar to Wieder's. Thus, the poet who is not a criminal ends up being an accomplice and poetry can hardly prevent and rescue him from the cycle of barbarism! There is no end to voyage from civilization to barbarism.

Distant Star besides is a novel about collective responsibility. Shortly before the murder of Wieder the narrator dreams that he is traveling in a big ship crossing a big ocean. There is party in the ship, then someone suddenly shouts, "Tornado! Tornado!" (Bolaño, 2009, p.122). The ship begins to sink. The survivors float in the ocean. The narrator sees Carlos Wieder clinging to a barrel of brandy while he is holding on to a rotten spar and it is at that moment he realizes:

Wieder and I had been traveling in the same boat; he may have conspired to have sink it, but I had done nothing or little to stop it going down. (Bolaño, 2009, p.122, original emphasis)

Thus, if Pinochet's coup d'état is a Chilean shipwreck in the middle of the ocean, Pinochet alone was not responsible for this political misfortune. Others are equally responsible and they must face the blame for they did nothing or little to stop the misfortune. Culture and violence were traveling in the same ship; culture and violence often travel in the same ship.

\section{Teaching Marxism to dictator and his men}

By Night in Chile dwells on the complicity of a failed poet, literary critic, and member of Opus Dei with Pinochet's leadership. According to Paz Soldán and Patriau (2013) this narrative leads the reader to ponder if artists can be blind to sufferings of the people and yet really write, compose poetry during authoritarianism and turbulent times. It reveals the weakness and hypocrisy of the so called "intellectuals" and "learned" societies when it comes to their relationship with power. In 
Stacy D'erasmo's point of view the narrative questions the intellectual elites' seriousness and their ability to write poetry, paint, discuss the finer points of avant-garde theater or literary aesthetics during repressive regime and at the same time be immune to the sufferings of the common mass as the military junta torture people in basements. She maintains:

... But what can it mean, he asks us and himself, in his dark, extraordinary, stinging novella "By Night in Chile," that the intellectual can write poetry, paint and discuss the finer points of avant-garde theater as the junta tortures people in basements? The word has no national loyalty, no fundamental political bent; it's a genie that can be summoned by any would-be master. Part of Bolaño's genius is to ask, via ironies so sharp you can cut your hands on his pages, if we perhaps find a too-easy comfort in art, if we use it as anesthetic, excuse and hide-out in a world that is very busy doing very real things to very real human beings. Is it courageous to read Plato during a military coup or something else? ("The Sound and the Fürher")

The Bolañian text reflects the relationship between literature/poetry and political crime, the writer and the totalitarian State, and puts the literary institution in crisis mode. According to Zalewski (2007), "A literary crime, in Bolaño's world, is the equivalent of a political crime" ("Vagabonds").

Although By Night in Chile does not deal with the theme of violence explicitly and there is no gruesome murder unlike what we have seen in Distant Star, Father Sebastián Urrutia Lacroix, the narrator-protagonist, ends up being an accomplice of brutalizing forces like the unnamed narrator of the previous novel. The action takes place at his deathbed one long feverish night when he tries to remember his other - the wizened youth, and everything that he has done and talks in monologue to justify his actions. The text reads like a long confessional story. Urrutia Lacroix with a vocation to religious and poetic life comes from a humble background having roots in Basque and French origin. At a tender age he enters a seminary much against the wish of his father and under the guidance of renown critic Farewell he develops passion for literature. However, his notion of literature is one that offers refuge. This is revealed when he has his first poetic communion at the critic's ranch. When Farewell invites him to his ranch, he is pleased and he thinks that he have found a literary refuge. However, his refuge is disturbed by the presence of peasant children covered in dirt and snot. This encounter produces nausea and revulsion in him and he really cannot tolerate them and thus reflects his disconnectedness from his immediate surroundings.

Urrutia Lacroix shares a poetic vision that is elitist, classicist and Eurocentric, and sees literature "as a space that allows one to escape from the world, especially from political events" (Marinescu, 2015, p. 350). So he voluntarily chooses to stay outside of the politically tumultuous times of recent history of his country and portrays himself as an intellectual functioning outside of politics. However, it is precisely this desire to function outside of politics that makes him a larger accomplice of violence. During his country's most turbulent time he goes back to reading classics. He hardly takes interest in the conflict or so called "progressive" movement gaining momentum in his country. He remains completely unaffected by the political turmoils. When Pinochet finally seizes power by bombarding La Moneda, the seat of the elected president of Chile, he is pleased to have found, "Peace at last" (Bolaño, 2003, p. 82). However, soon after the coup, he who sees literature as entity separate from his immediate surroundings, and sees no connection between the two, winds up teaching Marxism to Pinochet and his men.

He gives classes to Pinochet and his men. Pinochet reveals the motif behind studying Marxism under him in of the classes and informs him that of all the Chilean political leaders, he is 
the most erudite, he is the only one who has read and written books and according to the dictator himself, Allende used to read only magazines, summaries of books and articles that his followers used to cut out for him. He tells him:

And what do you think Frei read? ... Nothing. He didn't read at all. Not a word, not even the Bible. ... They didn't read, they didn't write. They pretended to be cultured, but not one of them was a reader or a writer. ... How many books do you think I've written? ... Three. ... Well, they're military books, military history, geopolitics, aimed at a specialist readership. ... I read books about history and political theory, I even read novels. ... Why do you think I want to learn about the fundamentals of Marxism? ... in order to understand Chile's enemies, to find out how they think, to get an idea of how far they are prepared to go. (Bolaño, 2003, pp. 98-100)

The text thus devalues Latin American revolutionary figures and strip them off their aura. Allende committed suicide during the coup. By accepting death for himself, he saved other Chileans from it. According to Bolaño it is, in fact, this specific act that has ennobled and made him huge in an immense way and not otherwise. Bolaño invites the readers to juxtapose the two Chilean political leaders and revisit history.

Freedom of expression, liberty are curtailed during dictatorship. There are curfews. Yet Urrutia Lacroix confesses that during Pinochet's regime some intellectuals are able to organize tertulia or poetic salon at night to discuss philosophy, politics, poetry, art, etc. María Canales who is a writer by profession and whose husband works as CIA torture specialist for the regime, offers cultural space at her house to members of the Chilean vanguard for intellectual discussion. She organizes literary get together where Chilean writers who are immune to dictatorship participate and discuss finer points of avant-garde aesthetics while her husband runs torture chamber in the basement of the same building. Urrutia Lacroix also participates in this intellectual engagement. It appears that in one of those regular gatherings one of the participants gets drunk, loses his way in the basement of the building while he was going to bathroom and instead he comes across a man tied to the metal bed, blindfolded. The man is alive and desperately cries for help. The guest can hear his breathing. However, he refuses to help him and he says nothing at all about him when he rejoins his friends in the gathering. Years later it is revealed that María Canales' husband used to torture political dissidents in the basement of their house.

The text thus problematizes our conceptualization/understanding of literary culture. Can intellectuals dwell on issues that concern humankind and be indifferent or immune to the sufferings of the people at the same time? By juxtaposing literary get together and torture chamber Bolaño again blurs the line between what is called culture and violence, exposes the hypocrisy or double standard of the intellectuals.

Carlos Wieder and Urrutia Lacroix are two different characters. Yet at bottom they share a commonality. The commonality is their love for poetry. If Wieder aspires to "revolutionize" Chilean poetry, Urrutia Lacroix envisions a kind of poetry that has never been practiced in the country. His literary project is thus no different from Wieder's. He connects the idea of "purity" with a story about German writer Ernst Jünger whom he describes as one of the purest man. Jünger was no doubt a conservative writer. However, despite his conservatism he opposed the Nazi regime, he was responsible for and instrumental in protecting the left-wing artists such as Picasso during the Vichy regime in France. For that matter Urrutia Lacroix is just the opposite of Jünger. He cannot raise above his narrow mindset, conservatism before, during and after the coup and therefore, he ends up becoming accomplice to the fascist regime. By juxtaposing Urrutia Lacroix against Jünger, Bolaño initiates the debate between culture and barbarism. 
The debate is carried on one step further by the use of symbolism. Bolaño very deftly uses falcon and pigeon as symbols of violence/culture in By Night in Chile. Urrutia Lacroix learns in Europe while he is on scholarship to study about preservation of the churches that the secret to clean church is falcon. In Europe falcons are used to chase away pigeons to keep the churches clean. The idea immensely enlightens him. However, it also confounds him. Since both falcon and pigeon are God's creatures, if we believe in religion, can we really use one soul against another in order to keep the house of God clean? Urrutia Lacroix puts the blame for his actions on the wizened youth, however his confessional tone of narrating the text does not absolve him.

\section{Conclusion}

Thus we see in the above mentioned texts that culture, by which I mean literary culture, and violence share intricate relationship, they share a gray area at times and it becomes extremely difficult to distinguish between the two. Both the texts challenge, puncture the traditional notion of literature as it is intrinsically linked with torture, murder, violence and it inhabits a barbaric dimension. Literature is not innocent or guiltless in these texts; it is never neutral. Bolaño thus offers us a new definition of literature, the one which is concerned with the ethics of the intellectuals - poets, novelists, artists, etc. Literature, for him, then is not just about writing, but also about culpability, compromise and "surrender" opposed to epic discourse of bravery, commitment and empowerment. It is a disappointment and rejection of all linked with power and it advocates, instead, for venturing to the most marginalized, the most hostile and the most inhospitable of life experiences where culture and violence overlap, coincide. The above mentioned texts journey us through these experiences.

\section{References}

Barthes, R. (n. d.). The Death of the Author. Retrieved from http://www.ubu.com/aspen/aspen5and6/threeEssays.html\#barthes

Benjamin, W. (1999). Illumination. (n.p.). H. Arendt (Ed.). (H. Zorn, Trans.). Pimlico.

Bolaño, R. (2003). By Night in Chile. (C. Andrews, Trans.). London: Harvill Press.

Bolaño, R. (2009). Distant Star. (C. Andrews, Trans.). London: Vintage Books.

Bolaño, R. (2009). Last Evenings on Earth. (C. Andrews, Trans.). London: Vintage Books.

D'erasmo, S. (2008, February 11). The Sound and the Fürher. The New York Times. Retrieved from http://www.nytimes.com/2008/o2/24/books/review/D-Erasmo-t.html

Lopez-Vicuña, I. (2009). The Violence of Writing: Literature and Discontent in Roberto Bolaño's 'Chilean' Novels. Journal of Latin American Studies: Travesia, 18(2-3), 155-166.

Marinescu, A. (2015). Fascism and Culture in Roberto Bolaño's "Estrella distante" and "Nocturno de Chile." Revista Canadiense de Estudios Hispánicos, 39(2), 341-365.

Zalewski, D.(2007, March 26). Vagabonds. Roberto Bolaño and his fractured masterpiece. The New Yorker. Retrieved from https://www.newyorker.com/magazine/2007/03/26/vagabonds

Mandeep Boro is an Assistant Professor at Department of English, Amrita Vishwa Vidyapeetham, Ettimadai. His area of specialization includes Latin American literature of the Twentieth Century, especially Gabriel García Márquez and Roberto Bolaño. His research interests comprise PostBoom poetry and Twenty-First Century Latin American narratives. He is PhD from JNU, New Delhi. 